\title{
"No CCP, No New China": Pastoral Power in Official Narratives in China
}

\author{
Xiaoling Zhang ${ }^{*}$, Melissa Shani Brown ${ }^{\dagger}$ and David O’Brien*
}

\begin{abstract}
Guided by Michel Foucault's concept of "pastoral power," this article examines the ways in which contemporary discourses within official narratives in China portray the state in a paternal fashion to reinforce its legitimacy. Employing interdisciplinary approaches, this article explores a number of sites in Urumqi, the regional capital of the Xinjiang Uyghur Autonomous Region (XUAR), in order to map how a coherent official narrative of power and authority is created and reinforced across different spaces and texts. It demonstrates how both history and the present day are depicted in urban Xinjiang in order to portray the state in a pastoral role that legitimates its use of force, as well as emphasizing its core role in developing the region out of poverty and into "civilization."
\end{abstract}

Keywords: Foucault; pastoral power; discipline; discourse; legitimacy; public space; Xinjiang

This article explores discourses across several "public spaces" in Urumqi, the main city in China's Xinjiang Uyghur Autonomous Region (XUAR), in order to explore how a coherent official narrative of "pastoral power" is created in spite of social unrest and ethnic violence. Taking a number of different public spaces as case studies, we explore what relationships are depicted or implied, and consider how this generates a field of meaning for and about those who inhabit this place. Expanding upon Michel Foucault's concept of "pastoral power," we trace the legitimation of the state's presence and use of force not only in visible symbols of discipline, such as the presence of tanks and security cameras or in news coverage of the trials of terrorists, but also at play more subtly within the reiteration of Xinjiang's complete dependency upon the Chinese state for any economic prosperity, social development or "ethnic harmony." We argue that it is in the emphasizing of the state's pastoral role, alongside the use of

\footnotetext{
* University of Nottingham (Ningbo Campus). Email: xiaoling.zhang@nottingham.edu.cn (corresponding author).

$\dagger$ University of Nottingham (Ningbo Campus).

+ University of Nottingham (Ningbo Campus). 
disciplinary force "to keep the population safe," that its legitimacy is derived. Such narratives aligning "stability," "development," "ethnic unity" and the importance of the leadership of the Chinese Communist Party (CCP) underpin China's current counter-terrorism strategy in Xinjiang.

The Chinese government's concept of ethnicity is based on Stalin's 1953 definition of ethnic/national groups as those sharing a common territory, language and psychological nature, scaled onto the particular stage of the Marxist progression of history (the primitive, slave, feudal, capitalist and socialist modes of production) that people had reached at the time of classification by the Communist ethnographers. ${ }^{1}$ This ethnic classification system led to the identification of 56 ethnic groups: 55 minorities and the Han majority (today numbering 92 per cent of the population). In Xinjiang, this process resulted in the official recognition of 13 ethnic groups - Uyghur, Han, Kazakh, Manchu, Kyrgyz, Hui, Mongol, Xibo, Tajik, Russian, Uzbek, Tartar and Daur. ${ }^{2}$ However, in contrast to the Soviet Union, which established a system based on federal republics with a theoretical right to secession, the People's Republic of China (PRC) instituted a system of limited territorial autonomy to manage ethno-national differences. ${ }^{3}$ Regional autonomy for ethnic minorities aimed to give them economic, administrative and language privileges, but any discussion of self-determination is strictly prohibited. Many scholars have argued that in fact very little political autonomy exists in the XUAR. ${ }^{4}$

Since 1978, the party-state of the PRC has stressed the equal citizenship of its 56 ethnic groups in one overarching "Chinese nation" in an attempt to avoid the kind of disintegration seen in the Soviet Union and to quell separatism in Tibet, Xinjiang and Inner Mongolia. The notion of a unified Chinese nation is closely related to the party-state's need to maintain stability within China in order to ensure its own legitimacy. In 2003, the Chinese government published a White Paper entitled "History and Development of Xinjiang," which states that "since the Western Han Dynasty (206BC-24AD) [Xinjiang] has been an inseparable part of the multi-ethnic Chinese nation." 5 The paper traces Chinese rule over the region to the present and declares it unbroken. This is the central aspect of government policy on all of the PRC's frontier regions: Xinjiang, Tibet and Inner Mongolia are now, and have always been, an inalienable part of China.

Anne-Marie Brady argues that despite numerous crises and challenges since 1989, "the symbols used and stories told" to emphasize national unity and social cohesion have on the whole successfully enabled the CCP to renew its widespread legitimacy and grip on power. ${ }^{6}$ While the region has shown rapid economic

2 Clarke 2011.

3 Ibid.

4 Moneyhon 2002; Stein 2003; Bovingdon 2010.

5 White Paper on "History and Development of Xinjiang," http://en.people.cn/200305/26/eng20030526_ 117240.shtml. Accessed 23 February 2016.

6 Brady 2008, 200, 202. 
development, XUAR has also witnessed numerous violent incidents - the most serious being the 2009 ethnic riots in Urumqi, which left almost 200 people dead, and the violence in 2014, which also spread to Inner China with attacks in Beijing and Kunming. Xinjiang has experienced different governance tactics since 2009. When Zhang Chunxian 张春贤, praised in the Chinese media for his use of social media to communicate directly with citizens during his time as Party secretary of Hunan, took over as Party secretary following the deadly ethnic riots of 2009, he adopted a more open approach. ${ }^{7}$ However, as sporadic violence continued, Zhang increased monitoring, with a particular focus on the rural south where Uyghurs are in the majority and where most of the violence since 2009 had occurred. In line with China's "mass line campaign," which started in June 2013, more than 70,000 officials had been dispatched to villages and communities in Xinjiang by April 2014 to "boost development and people's livelihoods." 8 These officials, many of them young university graduates who mostly are unable to speak Uyghur, were sent to rural areas across Xinjiang. Usually stationed in police stations, they visited villages under armed police guard to promote government policies and monitor and correct "undesirable behaviour and work styles." These tours of rural villages led to tensions and, in some cases, violence. ${ }^{9}$ In August 2016, the renowned hardliner Chen Quanguo 陈全国, former Party chief of the Tibet Autonomous Region, replaced Zhang as XUAR Party secretary. Chen quickly introduced some hard-line tactics to Xinjiang. According to Adrian Zenz and James Leibold, a total of 31,687 security-related positions were advertised in 2016, a more than threefold increase over the previous year. ${ }^{10}$ In the same year, the Shihezi 石河子 Public Security Bureau Immigration Office was reported to have ordered Uyghur residents to surrender their passports for "annual reviews." 11 February 2017 witnessed the largest military display of strength since the 2009 violence when more than 10,000 troops gathered in the centre of Urumqi and a number of other cities across the region. ${ }^{12}$ In 2017, new anti-terrorist legislation was introduced which prohibited the following:

- Advocating or propagating extremist thoughts;

- Wearing or forcing others to wear full-face coverings;

- Hyping up religious fanaticism through growing beards or choosing names in an abnormal way;

- Not allowing children to receive state education, interfering with state education;

7 O’Brien 2016.

8 “Mass line hits Xinjiang," Global Times, 21 April 2014, http://www.globaltimes.cn/content/855769. shtml. Accessed 16 August 2017.

9 Interview with local official, Urumqi, June 2015.

10 Zenz and Leibold 2017

11 Luu and Fang 2016

12 Philips 2017. 
- Deliberately interfering or harming the implementation of family planning policies;

- Publishing, downloading or reading articles, publications and audio-video material containing extremist content;

- Rejecting or refusing state products and services that include radio and television programming. ${ }^{13}$

The shift from a softer to a harder position, or the swing between "care" and “discipline," are most clearly expressed by Zhu Hailun 朱海仑, deputy Party secretary of XUAR: "[w]ith the caring and strong leadership of the Communist Party Central Committee, where President Xi Jinping serves as the core ... the strong support of $23 \mathrm{~m}$ people from all ethnic groups in Xinjiang, and with the powerful fist of the People's Democratic Dictatorship, all separatist activities and all terrorists shall be smashed to pieces." 14 It is in this context, where the official line has moved from a softer to a much harder position, that we explore how the state represents itself across various public spaces in Urumqi, and, to go back to Brady's argument, how the official narratives of national unity and social cohesion in Xinjiang work for all those present to enable the CCP to promote its legitimacy in this restive region.

In spite of the difficulties in carrying out empirical work in a region the Chinese government considers sensitive, ${ }^{15}$ scholars such as Dru Gladney, Justin Rudelson, Jay Dautcher and Joanne Smith have nevertheless researched Uyghur identity; ${ }^{16}$ others have focused on issues of ethnicity, nationalism and state-minority relations. ${ }^{17}$ There has also been a focus on the economic situation in Xinjiang in the overall context of the Chinese economic reform and opening up, and the increasing social and economic ties with its Central Asian neighbours. ${ }^{18}$ Yet, despite the upsurge in scholarly work on Xinjiang in recent years, there continues to be a shortage of research examining how power in Xinjiang's societal, political or cultural contexts works, and there is limited theoretical engagement with this context. Our research attempts to fill this important gap in the scholarly literature by addressing the following research questions: what narratives and symbols are presented in public spaces in Xinjiang, and how do they contribute to an officially generated understanding of Xinjiang and "power"?

To answer the questions, we explore what narratives of power are at play for all those who live in Xinjiang, braiding together analyses of the discourses from the local official media, the noticeboards and displays in the provincial museum, as well the signs and texts on an ordinary street. Following Foucault, "discourse" in

13 Hunt, Luu and Jiang 2017.

14 Philips 2017.

15 Yee 2003.

16 Gladney 1998; Rudelson 1997; Dautcher 2009; Smith 2002

17 See Bovingdon 2010; Gladney 2004; Moneyhon 2002; Mackerras 2001.

18 Clarke 2011; Howell and Fan 2011. 
this article refers to both written and spoken communications as well as semiotic sequences between and among objects, subjects and statements. ${ }^{19} \mathrm{We}$ argue that these very different texts, be they reiterating discourses of care, discipline or punishment, all echo the same narrative - it is only through a dependant relationship with the imperial dynasties previously, and the CCP currently and in the future, that stability and development are possible in Xinjiang.

\section{Theoretical Approach and Methodologies}

In this article, we presuppose Teun van Dijk's understanding of how the integration of the parts of any given text may function to construct ideology. ${ }^{20}$ In tracing continuities across these cases, we employ Foucault's "pastoral power" as a theoretical lens.

Power for Foucault is simultaneously an abstract concept and concrete social practice, but not one reduced to being negative: "[w]e must cease [solely to] describe the effects of power in negative terms: it 'excludes,' it 'represses' ... In fact, power produces; it produces reality; it produces ... truth." 21 This underpins our discussion; it is the "discourse of reality" as depicted in these texts that we are seeking to explore. Foucault's concept of pastoral power is adjacent to his engagement with power in texts such as Discipline and Punish. ${ }^{22}$ In focusing on the pastoral, Foucault does not abandon the concept of discipline, but instead concentrates upon a "notion of government" in which power figures itself as essentially caring for its population..$^{23}$

Foucault describes pastoral power as being "the idea of a pastor-sovereign ... [a] judge-shepherd of the human flock ... 'government' understood as an activity that undertakes to conduct individuals throughout their lives by placing them under the authority of a guide responsible for what they do and for what happens to them." ${ }^{24}$ In "Security, territory, and population," Foucault traces the genealogy of this discourse in religious institutions, in which power is both described as and legitimated through the Church's responsibility for its flock. ${ }^{25}$ The metaphor of shepherd and flock has its origins in ecclesiastical terms but also serves to emphasize the ambivalence of this power relation: the shepherd cares for his flock but also owns them, and determines their fate as well as their welfare. Key to Foucault's argument is that this conceptualization of power is not limited to religious institutions, and the state taking on responsibility for its population functions as a discourse which also legitimates its use of force - which is particularly noticeable if we consider the overlap between welfare and security.

19 Foucault 2002.

20 van Dijk 1998.

21 Foucault 1977, 194

22 Ibid.

23 Foucault 1994, 67

24 Ibid.

25 Foucault 1994. 
This ambivalence is highlighted by Barry Hindess, who describes pastoral power as a metaphor "[implying] that the aim of government is to promote the well-being of its subjects by means of detailed and comprehensive regulation of their behaviour ... Pastoral power, as Foucault presents it, is concerned more with the welfare of its subjects than with their liberty." ${ }^{26}$ While this conceptualization emphasizes the government's good intentions, it simultaneously situates the shepherd in the position of authority to determine what constitutes this wellbeing. In effect, to claim the role of shepherd, power must cast its population as "sheep" in need of such care.

Considering pastoral power, Foucault neither abandons the central role of discipline nor the discursive construction of a population into docile bodies. It is an etymology of police/policy that underpins Foucault's seminar in "Security, territory, and population." 27 Beyond simply meaning "police force," the broader meaning of police is the theory and analysis of everything "that tends to affirm and increase the power of the state to make good use of its forces, to obtain the welfare of its subjects," and above all, "the maintenance of order and discipline." ${ }^{28}$ Pastoral power works through these combined aspects: the use of police and other disciplinary institutions, and "the formation of individuals who can normally be relied upon to impose an appropriate rule on their own behaviour." ${ }^{29}$ The aims of pastoral power are not altruistic in being solely concerned with a population's well-being, but rather aimed at the power that a stable society has in relation to others. The aims of such police/policy are to create a state which can compete with others by creating internal "wealth-tranquillity-happiness." 30 Therefore, the purpose of pastoral power, despite the apparent humanitarian discourse of concern for a population's welfare, is ultimately the state's own stability, and economic and military strength.

Foucault's pastoral power has received limited academic engagement, and Foucault himself did not expand this discussion. While acknowledging that some might criticize the use of a Western concept in a Chinese context, our analysis does not aim to posit that Foucault's work might be used uncritically as a generalized explanation (either of China, or any particular society). We could point out both Foucault and van Dijk's concepts of language and power correlate with Mao's vision of the power of language, as set out in Yan'an 延安 in 1942, where "conformity with a specific public vocabulary of political terminology approved by the Party" was carried out "on the assumption that politically correct language causes politically correct thinking and behaviour." ${ }^{11}$ We also feel that criticizing analyses on the grounds of an unbridgeable difference between Western and Chinese contexts makes problematic presumptions: first, it sets

31 Chilton, Tian and Wodak 2012, 10. 
aside any actual engagement with analyses, so that rather than discussing particular cases, they are occluded from the start in a genetic fallacy (the presupposition that the origin of an idea determines whether it is true or false); second, it presumes that there would be nothing problematic about applying Foucault in a Western context, rather than acknowledging the debates around Foucault's concepts in the West. Our use of Foucault also involves some appropriation: some characteristics of pastoral power, such as "the shepherd's power is exercised not so much over a fixed territory as over a multitude in movement toward a goal," 32 seem only partially applicable to Xinjiang (territory is very much at stake, although there are certainly the twin goals of development and stability). Thus, our aim here is not a rigorous close reading of Foucault but to explore patterns in the legitimation of power, to which Foucault's concept offers itself as a valuable searchlight.

This article takes an interdisciplinary methodological approach. Our methods are broadly those of discourse analysis but adapted to consider these different types of public space, and content analysis, enhanced and contextualized by the review of scholarly works, analysis of official documents, site visits, and interviews with local media professionals, students and officials. While attending to representations across these discourses, we also consider what is absented, and how this interplay constructs an over-arching narrative. We believe that while examinations of the information notices and displays in the Urumqi Museum throw light on the official cultural and historical narrative of history and culture in XUAR, a study of Xinjiang Daily, the main official newspaper in Xinjiang, gives us official media's narrative of the present context of the ethnic group on the other. Our consideration of Friendship Road (Youyi lu 友谊路), a busy commercial street in downtown Urumqi, involves us thinking about a public space as one which might be "read," certainly as one dense with texts and signs intended to be read by those who inhabit this space. Our engagement with these varied discourses aims to reveal what narrative patterns might emerge across them, considering them as different facets of the same space for those who inhabit Urumqi.

\section{The XUAR Museum}

The XUAR Museum in Urumqi contains a variety of historical artefacts and cultural exhibits on Xinjiang's ethnic groups, throughout which the themes of "ethnic harmony," "stability" and "development" are emphasized. Our analysis of the museum notices and exhibits as we found them in June 2015 does not aim to reveal the museum as a political space (the political nature of official museums being a widely accepted point) but rather to engage with the museum as a space which represents official narratives. All quotes below are taken from the English language notices, which were compared to those in Chinese. They are quoted 
verbatim with some omissions for conciseness. The permanent display, "Ethnicity Exhibition," aims to represent the 12 main ethnic minorities in Xinjiang and portrays them with waxwork dioramas dressed in traditional costumes, often in front of recreations of yurts or mudbrick homesteads. All 12 of the minority groups are depicted in this bucolic fashion, presenting a timeless ethnicity in which styles of dress and forms of housing or agriculture remain undifferentiated across the entirety of the past. What is noticeably absent from this representation is the Han as an ethnic group. This presents a contradiction, since it is simultaneously stated that the region has always been part of China, and Han people have lived there for centuries, and yet they are not included as one of the ethnic groups or shown as having a history or traditions in this place - ostensibly because despite being acknowledged as an ethnic group, the Han people are always situated as the "modern" majority, even though historically they have not been the majority in XUAR. ${ }^{33}$ It is also striking that while many of these groups are so clearly cross-border in origin and name (Kazakh, Uzbek, Kyrgyz, Russian), narratives of such transnationality are absent. Indeed, the border is specifically mentioned as something needing to be protected rather than a conduit of people, culture and trade:

Xinjiang has been a multi-national homeland since ancient times. Forty-seven nationalities live here today ... For a long time, they have cooperated as one family to build and safeguard the borderland. ${ }^{34}$

The information notice board not only reiterates the timelessness of this depiction (it has "always" been like "this"), but also implies a complete absence of any conflict except with the "outside" - all of the various ethnic groups have only ever worked together in brotherhood ("as one family"). The need "to build and safeguard the borderland" not only naturalizes Xinjiang as a border region (peripheral to "Inner China" rather than being centred in itself), but also simultaneously implies Xinjiang's need to be built (to be developed) and to be safeguarded (to be defended against others). The theme of the need for development and stability is a recurring one, implying a lack of independent development, and the precariousness of peace.

Despite the Han's absence from the dioramas, it is the history of Xinjiang as part of the empire which is the focus of all the notices. ${ }^{35}$ Across these notices, it is the various imperial dynasties which are depicted as responsible for the stability and trade in Xinjiang:

The Unification in the Han Dynasty Created a New Era: In 60BC ... the Western Regions formally [were] incorporated into the territory of the Han Dynasty, becoming an inseparable part of the great motherland. In the unified political situation, land reclamation and border areas guard with the unimpeded Silk Road, not only promoted the economic and cultural exchanges

33 According to the Xinjiang Statistical Yearbook published in 2012, the Han population increased from $7 \%$ in 1953 to $40 \%$ in 2010. See Xinjiang Uygur Autonomous Region Statistics Bureau 2012.

34 Museum Information Notice.

35 Most information notices are in Chinese, Uyghur and English. 
of the East and West, but also provided a strong impetus for the economic and cultural development and prosperity of the Western Regions. ${ }^{36}$

Tang Dynasty Founded Military Viceroy's Office in An'xi: ... Tang Dynasty was founded in 618 and respectively established Military Viceroy's Office [...] under the jurisdiction of the central government ... The inhabitants of the Western Regions lived in harmony, which formed a diverse situation of multiple religions, languages and arts. Tang Dynasty also enhanced frequent exchanges with the Central Asian, West Asian, and European countries, which formed the economic and cultural prosperity of China's feudal society, so the history of the Western Regions entered a new era. ${ }^{37}$

When not printed on a plain background, such text is often overlaid over sepia photographs of the natural environment such as the Taklimakan desert - a visual means of adding both "age" to the history (connoted by the sepia images) while "nature-ing" Xinjiang (in being not-urban) but also grounding such descriptions of political unity as being equally natural and age-old. Like the dioramas, the textual description is idyllic: "becoming an inseparable part of the great motherland," "[t]he inhabitants of the Western Regions lived in harmony." As with the previous notice, there is neither mention of the numerous religious and ethnic conflicts throughout the region, nor documentation of the migrations of different groups. There is only reiteration of harmoniousness and cooperation, and how each imperial dynasty such as the Qing, Tang or Han brought "new eras" to Xinjiang. In each of these notices, it is the dynasty which is discursively responsible for the new era it heralds: the Tang Dynasty "enhanced frequent exchanges ... which formed the economic and cultural prosperity of China's feudal society." The Han Dynasty created the "unified political situation" which stopped any "impediments" to the Silk Road. In effect, the region has no history outside of the empire, and no trade or development was possible without the presence of the empire. While this glosses history, it also represents all progress and development as being the direct results of the stability only offered by being part of Imperial China - the idyll of each new era implies a mirror image of times without such peace or prosperity, times which narratively can only be situated outside the empire, beyond the safely guarded border, and temporally outside of each new era. Here, power situates itself as being responsible for the population's safety, and for the stability of society - a pastoral role, rather than a colonial one.

Another implicit correlation between Xinjiang and Inner China is constructed through the display of the museum's famous mummies. These mummies, such as the red-haired Cherchen Man, who died around 1000 BCE, and the Beauty of Loulan, who retains her seemingly Indo-European features and dates from $1800 \mathrm{BCE}, 38$ are placed alongside a Han official from the 1700s, implying that both in death as in life the Han and the various people of the area have lived side by side in harmony. The placement of the mummies alongside each other also collapses the histories of migration in the region into another timeless

38 Mallory and Mair 2000. 
image in which, by placing the Han official alongside these significantly older mummies, they are constituted as also having "always been" Chinese.

Discursively, the various dynasties are framed as bringing progress to the region, thus situating Xinjiang as lacking in modernity without this dependent relationship, but also circumnavigating any interdependency (Inner China needing the trade routes of which Xinjiang was a central part). It also situates the empire as concerned primarily for the development of the region as though this were altruistic. For Foucault, it is not that such development or stability is a lie, but that the ultimate aims of a state ensuring its population's "wealth-tranquillity-happiness" is ultimately its own stability, and the ability to develop economically and militarily, something very evident in Xinjiang and China more generally. ${ }^{39}$ If museums function as a public space, representing official narratives of the past, what is depicted in the provincial museum is a history which casts Xinjiang in the role of dependency upon the empire, and the various dynasties ultimately helping it into the present. In this particular context, the ethnic pasts are depicted as backward but essentially peaceful, and the empire was only ever a stabilizing force. The harmoniousness of society is naturalized, situating any form of conflict as historically unnatural, an outside which everyone ought to safeguard against. But this also foregrounds the significance of mobilizing the past as a discourse for pastoral power - ultimately the museum is less a repository of artifacts than a space constructing a narrative through which it is the present that is made meaningful.

\section{Xinjiang Daily}

In shifting our discussion to news media, we consider the discourses describing "the present." While the media landscape in China has been decentralized and commercialized since the 1980 s, state media is still involved in defining the boundaries of discourse. The removal of Xinjiang Daily editor Zhao Xinwei 赵 新尉 in November 2015 for having “improperly discussed" Party policies in the region clearly indicates that official media remains a site for the CCP's continued control of formal discourse. ${ }^{40}$ Interviews with Xinjiang Daily professionals confirmed that its core audience are officials at various levels within the administrative hierarchy in Xinjiang. ${ }^{41}$ As a political tool, Xinjiang Daily continues to serve as a mechanism of power which shapes and defines the official sphere of thought and expression.

We chose 2014 for analysis because it was one of the most violent years since 2009. In our analysis of Xinjiang Daily, we considered headlines, captions and the ordering of topics. These, as Allan Bell argues, can tell us "a lot about the

39 Foucault 1994, 70.

40 Ye 2015.

41 Four interviews with local media professionals were conducted in May and June 2015, three face-to-face and one over the telephone. Because of sensitivity, the interviewees remain anonymous in this article. 
character of the stories - indications of how they were made, evidence of discrepancies and gaps, and manifestations of the news values behind them." 42 Teun van Dijk holds similar views: "Language and discourse have a broad range of structural possibilities to emphasize and de-emphasize information and hence also the ideologically controlled opinions about groups." $\$ 3$

Xinjiang Daily has four language versions: Mandarin, Uyghur, Kazakh and Mongolian. Owing to accessibility and financial constraints in translation, we examined the Mandarin and Uyghur versions for the whole of 2014, and the Kazakh version for the second half of the year. We have chosen to use constructed week sampling, which is widely agreed to be a highly representative method. ${ }^{44}$

Our analysis shows that while some themes are common to all, others are specific to language editions only. The five common themes are: (1) overviews of the CCP leadership's activities; (2) the activities of cadres sent to Xinjiang as a result of Xi's mass line campaign; (3) the importance of the rule of law; (4) condemnation of terrorism, and the execution of terrorists; and (5) Uyghurs expressing their love for the CCP. The repetition of these themes across all versions renders them central - that is, they are the core messages which every ethnic group member ought to know. The first two are an explicit self-depiction, highlighting the official position on various issues as well as governmental programmes. The third theme acts as an abstract justification of the first two - the conceptual reiteration of the CCP as the law, and the importance of law, without which there would be instability - an instability made explicit in the fourth theme. The fourth core theme, which focuses on terrorism, tended not to describe any violence in detail; it only reiterated the leadership's condemnation of such violence but drew attention to the execution of those found guilty of terrorist activities. The recurrence of Uyghurs "expressing their love for the CCP" across all three language versions highlights suspicion: it is implied that it is the Uyghur ethnic group which needs to explicitly express love. This has the twofold effect of simultaneously making any tension an ethnic issue, since it is only one group making such demonstrations, while implying that any Uyghurs who do not express their love for the CCP are deviant from other Uyghurs. We found an absence of detailed reports on violent clashes in all versions, although there are reports on how the government is dealing with violence - this emphasizes the role of the government's response, while the lack of detail in describing violence makes it abstract, and also renders it senseless by not engaging with any reasons or motivations.

The Mandarin version has the most diversified content, and the highest production values, ranging from 8 to 12 pages each day. There were also therefore a wider number of recurring themes. In addition to the common ones, it also 
included: calls to encourage support for Xinjiang from regions of Inner China; the importance of ethnic unity; the importance of strengthening the leadership of the Party; and the problems of foreign entities in China such as Pizza Hut.

While a number of these recurring themes highlight the tension in the region, such as the focus on the importance of the rule of law and the importance of ethnic unity, some tap into other discourses. The calls for support from Inner China reiterate that Xinjiang is a space in need of Inner China, without which it could not modernize. Despite the fact that this could imply a binary relationship between Inner China and Xinjiang (the Frontier), the focus on the problems of foreign entities in China highlights how discursively China as a whole is situated as the "self." The situating of Pizza Hut or McDonald's as a foreign problem also serves to reiterate an idea of a homogenous and "pure" Chinese culture, which these signifiers of Western culture intrude upon - an idea itself rendered problematic when considering Xinjiang's position as part of the Silk Road and a site of cultural diversity and fusion. This also - under a different guise - reiterates some of the themes from the museum: the need to safeguard the region from something beyond its borders and an expectation for all ethnic groups to align themselves to this common goal.

One interviewee revealed that while the Uyghur version receives more resources than the other minority language versions, overall, the non-Mandarin language versions were generated simply by translating the Mandarin version, or just filled with literary essays and poems. In contrast to the Mandarin version, the Uyghur edition has far fewer pages, usually eight at most. Despite the comparative brevity, there is a variety of recurring themes. In addition to the common themes, others include highlighting the relationship between stability and reform; the support Xinjiang is receiving from Inner China; the importance of economic development; the importance of ethnic unity; the importance of the leadership of the Party; the need to remove extreme religious practices; and practical information (for example, health tips).

The theme focusing on the support Xinjiang receives from Inner China, together with the absence of Xinjiang's contribution to Inner China, highlights the relationship of dependence rather than interdependence. The next three themes are all "importances," which become intertwined: without ethnic unity and the leadership of the Party, there would be no economic development. This creates a strikingly similar narrative to that presented in the museum. The recurring theme of the need to remove "extreme" religious practices both situates (extreme) religion as a problem, and also creates a binary between extreme and moderate practices within religion. The implication here is also that this becomes the responsibility of those who practise the religion to police themselves - and others - for such extremism. Also unique to the Uyghur version, space is given not only to economic development but also to the relationship between development and stability, indicating that stability is paramount and is the only way to develop. However, this also implies that it is the Uyghurs who are responsible for this (in)stability, since it is in this language version that such emphasis is added. 
Topics are also highlighted to different extents in the various editions through their placement in the paper. Table 1 shows some examples. While it is on the second page of the Mandarin version, the topic of "Providing moral support for development, stability and long-term security" is moved to page one in the Uyghur version, showing the attention drawn to such development and stability. The prominence of the "Call to increase the level of support to Xinjiang" is stressed to Uyghur readers by moving from page two of the Mandarin version to page one of the Uyghur version. This foregrounds the dependency of Xinjiang, rather than the interdependence between all regions (despite the reiteration of "unity"). Again, the two articles on religion, "Islam promotes and observes 'moderation'," and "Stick to 'moderation' and leave extremism" are differently placed: while in Mandarin the former is on page three and the latter on page four, in Uyghur both of the articles are brought forward to page two. The different ordering of the topics reveals that religion is made prominent to Uyghur readers. What this discursively constructs is a particular understanding of what the problem is, or what its causes are. Here, it is religious extremism and a lack of economic development, which are situated as the causes of ethnic tension. Responsibility here is ambiguous though: it is the Uyghurs' responsibility to police [their] religious practices, and also to balance development and stability; however, it is Inner China's (and the CCP's) responsibility to support Xinjiang.

In contrast to either the Mandarin or Uyghur versions, the Kazakh edition has the lowest production quality, being heavily text-based and with any pictures published in black and white only, and usually ranging from four to eight pages per day. Partly owing to the brevity, the themes in this language version are also fewer. In effect, the Kazakh version contains little more than the core themes across all languages, and "fillers" - a large number of essays and stories.

We might trace patterns of pastoral power more explicitly in the newspapers than in the provincial museum. The recurring themes across the different language versions reiterate the dependency of Xinjiang upon Inner China and the importance of the leadership, as well as the dangers of religious extremism and terrorism, constructing a narrative in which stability and development are what is being offered by the government to the region. We might recall that pastoral power works through the combined use of disciplinary institutions, as well as "the formation of individuals who can normally be relied upon to impose an appropriate rule on their own behaviour." ${ }^{45} \mathrm{We}$ can see the intertwining of the use of force and the focus on welfare, and we can trace both of these in the news articles, from the recurring theme highlighting the importance of the rule of law and the repercussions (execution) for those involved in terrorism, as well as the enjoinders for Muslims to police themselves and others against extremism, and also in the banality of it being only the ethnic minority papers which include health tips. In this, we can perceive Foucault's twofold etymology of police/ 


\section{Table 1: Common Themes on Different Pages}

\begin{tabular}{|c|c|c|c|}
\hline Date & Titles & $\begin{array}{l}\text { Mandarin } \\
\text { version }\end{array}$ & $\begin{array}{l}\text { Uyghur } \\
\text { version }\end{array}$ \\
\hline 09.04 .2014 & $\begin{array}{l}\text { "Providing moral support for scientific } \\
\text { development, social stability and long-term } \\
\text { security" }\end{array}$ & 2nd page & 1st page \\
\hline 17.05.2014 & "Call to increase the level of support to Xinjiang" & 2nd page & 1st page \\
\hline 17.05.2014 & "Islam promotes and observes 'moderation"” & 3rd page & 2nd page \\
\hline 17.05.2014 & "Stick to 'moderation' and leave extremism" & 4th page & 2nd page \\
\hline
\end{tabular}

policy, in which it simultaneously means "the maintenance of order and discipline, [and] the regulations that tend to make their lives comfortable." 46 The newspapers create an official discourse of what the situation is in Xinjiang. The discourses on the need for security and development - that which is lacking and needing to be brought to Xinjiang - are strikingly recurrent across both the contemporary news articles and the museum notices, in effect telling the same narrative. However, the lack of any mention of ethnic (or religious) tension in the museum places the idylls of the past in contrast to the de-historicized contemporary violence.

\section{Friendship Road}

Friendship Road is one of Urumqi's busiest commercial streets and it is this space and the various signs within it that we explore next. In considering what meaning these signs communicated we did not confine ourselves to posters and advertisements; we also broadened our consideration of what was acting symbolically in this place.

Concerning the physical space of the street, there were noticeable barriers demarcating one space from another. These included checkpoints with soldiers and tanks, barbed-wire gates, metal detectors and blockades in the entrances to many buildings including hotels and shopping malls. These barriers parcelled the spaces through which one might move, and the need to pass through each barrier served as a visual and physical reminder of who is in control of this space. Ostensibly, these were security checkpoints and barriers, reinforcing the concept of their presence being a means of ensuring civilian safety, but they simultaneously served as a threat to any who might challenge this security. There was thus a twofold threat of violence embedded in the presence of such defences they implied the existence of a threat of violence from terrorism, which people must be protected from, but simultaneously constituted their own threat of violence against this terrorism. The armoured vehicle and the barbed wire thus served as multi-valent images of violence, interpellating subjects in different 
ways, but also speaking of the violence of the immediate past and disciplinary stability projected into the future. This was a distillation of pastoral power into a concrete image: the use of both discipline, and in this case also the police and military, and symbols of violence, such as the armoured tank and barbed wire, explicitly for protection, for security, to ensure the stability of the city and the safety of the population.

Some of the posters on Friendship Road also reiterated this message. The poster "Enhance our vigilance and take strict cautions against terrorists; strengthening safety and precaution is everybody's responsibility" (tigao jingti, yanfang bao kong; jiaqiang anfang, renren youze 提高警惕, 严防暴恐; 加强安防, 人人有责) overlays red texts against a generic image of snowy mountains and green fields. The generic landscape reiterated the timeless narrative of a natural harmoniousness, implying the opposite for whatever disrupted it. The text itself concerned the need for everyone to be vigilant, but in so doing implied an underlying "self" and "other" in which "we" must be vigilant and take precautions, and terrorists, by implication, were neither addressed nor part of this "self." We found here the same implied meaning as that presented in the museum: a past rendered peaceful (although more agricultural than modern) in which everyone idyllically worked together to safeguard this border region against an externalized enemy.

Many such posters were part of bus shelters, but others were printed on barriers separating pedestrian areas from parking or the street. One of the street posters contained the caption "No CCP, No New China" (meiyou gongchandang, jiu meiyou xin Zhongguo 没有共产党, 就没有新中国), and depicted four figurines of Uyghurs playing music and singing. Although captioned both in Mandarin and Uyghur, the Mandarin script was significantly larger and emphasized, appealing both primarily to Mandarin readers but also reiterating that Mandarin is the dominant language. Through its caption, this poster might be likened to a continuation of a number of discourses which we first examined in relation to the provincial museum: explicitly only through its relation with China and the CCP may Xinjiang become new and modern.

The toy-like representation of the musicians on the posters invites comparison to Mazia Varutti's analysis of miniatures in ethnic museums: "Albeit ethnic minority figurines usually depict adults rather than children, it could be argued that the miniaturized figurines ease the infantilization of ethnic groups ... The figurines of ethnic minorities in Chinese museums might be compared to toys." 47 The figurines we saw were both toy-like and childlike (with oversized heads and baby-like faces), and could play out a variety of stories of the past, present or future: as a generic depiction of Uyghur ethnicity, rendered always traditional (and not, for example, as a brain surgeon or engineer), an idealized depiction of ethnic harmony, or as celebrating the bringing of "New China" to Xinjiang by 
the CCP - another new era, as in the museum. The infantilization at play in this image was complex, rendering both the Uyghurs as childlike (and therefore implicitly also in need of protection, of someone to look after them) and likewise any viewer, by inviting an imaginative engagement with these "toys." Unlike Varutti's museum exhibits, this poster was present in the very place it represented; the time, place, and people it depicted were also beyond the space of the poster, but they were driving cars, working in offices, and navigating security checkpoints. The implication of both the Uyghurs and any viewer as being childlike in the context of Friendship Road correlated this need to be looked after into the environment itself: the CCP is responsible for bringing the new era of New China to Xinjiang, and for looking after the ethnic minorities as well as the population passing along the street filtering through the checkpoints.

This public space was busy with various discourses, ranging from the official notices reminding passers-by that without the CCP there would be no new China (modernity/prosperity) or warning passers-by against terrorists, to commercial advertisements promoting expensive products as commodities of the successful. And yet across these various discourses there remained particular themes: that stability was at stake in this space, that individuals were responsible for being vigilant, working hard and for making themselves (and thus Xinjiang) successful. The possibility of a better life, and a new China, was safeguarded by these checkpoints, as was the possibility of conspicuous consumption, be it the advertisements of expensive alcohol or the mall with designer brand outlets only accessible via metal detectors. This varied space became the idea of the public space that was being defended, and thus also discursively the public space that was under attack.

Our observations of Friendship Road were carried out on "ordinary" days, and our analysis focuses on discourses present in the quotidian rather than the exceptional. We argue that it is precisely by focusing upon the banal that we can study that which is taken for granted within this space. What is writ in such spaces is a self-depiction of the state, and as the mass military anti-terror rallies by security personnel in Urumqi and other cities in February 2017 highlight, public spaces are precisely those which are mobilized to tell official symbols and stories.

\section{Discussion and Conclusion}

It must be emphasized that the museum, newspapers, and symbols in public places operate together for those who inhabit these spaces, creating a field of meaning and a coherent discourse: an over-arching narrative in which progress will only be made through unity with China and the CCP. Progress, stability, development, and modernity become interwoven and come to implicate each other. Such discourses function not only to represent history or current events but also to depict the state in a paternalistic fashion which legitimates its presence and use of force. The focus upon concepts of stability and development 
emphasize the pastoral: it offers a single narrative in which these positive things are provided only through harmony with China. These discourses are a means through which power legitimates itself, focusing upon what is described as the welfare of the population, working simultaneously through discipline, and the encouragement of a population which accepts the representation of official narratives (of progress, history, identity, and what constitutes its welfare) - an acceptance inculcated at least in part through these various mediums of museums, news and public posters, co-existing with tanks, metal detectors and a high level of surveillance cameras.

What is at issue here is that the narratives constructed across these texts and symbols focus upon themes such as development and stability to construct a dichotomy between the welfare and development of Xinjiang, and by contrast implicit conflict, poverty and "backwardness." This constructs a binary choice in which the welfare of Xinjiang and its population is only assured through the CCP. This is done by creating a historical arc through which any development in the past was only achieved through unity with Imperial China, and currently through being developed by the CCP and with the support of Inner China; any narratives of the possibility of development, modernity or stability that is not mediated by the Chinese state are completely circumnavigated. We can see here how power not only functions through force but also simultaneously through discourses that highlight everything that the state does for its citizens. Like a carrot and stick, power implies the possibility of disciplinary violence while explicitly framing the government as caring and bearing responsibility.

Such discourses are neither unique to China nor indeed to Xinjiang. It is beyond the scope of this article for us to explore the ways in which the CCP represents itself across other regions of China as a pastoral power; however, what may be significant in Xinjiang is the extent to which these discourses are historicized into the empire, and also become "ethnicized" - rendered not only in terms of the state's responsibilities towards its general population but also in situating particular ethnic groups as those in need of modernization as well as protection. The same discourses of being primarily interested in development and safeguarding the borderlands extend across the museum's narratives of the past and the other texts' depictions of the present; perhaps, ironically, this also implicitly renders the CCP heir to all imperial dynasties in Xinjiang, since these are depicted as always being concerned with stability and promoting the development of the "New Frontier." Zhu Hailun's declaration that it is with "caring and strong leadership ... [that] all terrorists shall be smashed to pieces" most aptly encapsulates pastoral power - the intertwining of discourses of responsibility and discipline, and the legitimation of the latter through the former, being the crux of Foucault's concept - and also appears to be key to understanding the discourses of power in Xinjiang. ${ }^{48}$ 
Considering the recurring themes across these sites renders pastoral power as potentially at play within discourses far more varied than the ecclesiastic ones Foucault first took inspiration from, and also divergent from those focusing upon either prisons, hospitals or other such disciplinary institutions. It also allows us to consider the potential subtlety of such discourses - at play both in museum depictions of the past as "barbaric" or "bucolic," because what is of significance is the purpose behind the contrast with the present, and also in the heightened security and surveillance, an increasingly familiar sight across the world. It also allows us to consider the potential persuasiveness of such discourses. Highlighting only harmonious pasts and new eras, particularly in a context where significant effort is put into development, makes the notion of unity appealing and any rejection of it senseless - senseless in that it appears to be a rejection of everything that is discursively situated as positive. What is perhaps most striking in this context is not that we might identify the symbols used and stories told to produce the CCP's legitimacy in Xinjiang, but rather that the outbreaks of violence simultaneously belie the idyllic depictions and, in themselves, re-legitimate the discourse of the need for a pastoral-disciplinary power to maintain stability.

\section{Biographical notes}

Xiaoling Zhang is chair professor at the School of International Communications, University of Nottingham (Ningbo Campus). She has published widely on the shifting political, cultural and media landscapes in China and China's recent promotion of soft power and public diplomacy.

Melissa Shani Brown is assistant professor at the School of International Communications, University of Nottingham (Ningbo Campus). Her research explores the contrasting meanings of silence across various discourses, drawing from a range of cultural texts including non-fiction writing, poetry, testimony, film and art.

David O'Brien is assistant professor at the School of Contemporary Chinese Studies, University of Nottingham (Ningbo Campus). His research focuses on ethnographic studies of Xinjiang, and in particular, his work engages with the construction of Uyghur identity and the representation of ethnicity within China more broadly.

\footnotetext{
摘要: 本文着眼于探讨在中国新疆这个多事地区, 官方是怎样在不同的公众 场景里讲述一个政府关爱百姓的故事。本文作者利用采用并延伸了福柯 “牧师关爱”理论, 用多种学科的研究方法 - 对新疆博物馆里的说明文以及 展出物品的分析, 对新疆日报的分析以及乌鲁木齐市中心友谊路上的路 标、广告牌的内容等等的分析, 再加上访谈, 提出, 不论是博物馆里对于 历史的讲述, 新疆日报反映当下的叙述, 还是出现在 友谊路上对现在或 者将来的话语, 无一不是在讲述同一个故事 - 它不仅代表了官方对历史
} 
或者是当下的话语, 也展示了国家对子民父爱般的话语, 以达到在新疆存 在和行为的合法化。

关键词: 福柯; 关爱; 惩罚; 话语; 合理; 公共领域; 新疆

\section{References}

Bell, Allan. 1998. "The discourse structure of news stories." In Allan Bell and Peter Garrett (eds.), Approaches to Media Discourse. Oxford: Blackwell Publishers Ltd., 64-105.

Bovingdon, Gardner. 2010. The Uyghurs: Strangers in their Own Land. New York: Columbia University Press.

Brady, Anne-Marie. 2008. Marketing Dictatorship: Propaganda and Thought Work in Contemporary China. Lanham, MD: Rowman and Littlefield.

Chilton, Paul, Hailong Tian and Ruth Wodak. 2012. Discourse and Socio-political Transformations in Contemporary China. Amsterdam: John Benjamins.

Clarke, Michael E. 2011. Xinjiang and China's Rise in Central Asia 1949-2009: A History. London: Routledge.

Dautcher, Jay. 2009. Down a Narrow Road: Identity and Masculinity in a Uyghur Community in Xinjiang China. Cambridge, MA: Harvard University Press.

Foucault, Michel. 1977. Discipline and Punish: The Birth of the Prison. London: Penguin.

Foucault, Michel. 1994. "Security, territory, and population." In Paul Rabinow (ed.), Essential Works of Foucault, 1954-1984. Vol. 1. Ethics: Subjectivity and Truth. New York: The New Press, 67-72.

Foucault, Michel. 2002. The Archaeology of Knowledge. London: Routledge.

Gladney, Dru. 1998. Ethnic Identity in China: The Making of a Muslim Nationality. Fort Worth, TX: Harcourt Brace.

Gladney, Dru. 2004. Dislocation China: Reflections on Muslims, Minorities and Other Subaltern Subjects. Chicago: University of Chicago Press.

Ha, Louisa. 2012. "Sampling in international advertising research." In Shintaro Okazaki (ed.), Handbook of Research on International Advertising. Cheltenham: Edward Publishing Limited, 231-251.

Hindess, Barry. 1996. Discourses of Power: From Hobbes to Foucault. Oxford: Blackwell.

Howell, Anthony, and Cindy Fan. 2011. "Migration and inequality in Xinjiang: a survey of Han and Uyghur migrants in Urumqi." Eurasian Geography and Economics 52(1), 119-139.

Hunt, Katie, Chieu Luu and Steven Jiang. 2017. "Why China is banning beards and veils in Xinjiang," CNN, 1 April, http://edition. Accessed 16 August 2017.

Luu, Chieu, and Nanlin Fang. 2016. "China orders Xinjiang residents to surrender passports to police,” CNN, 25 November, http://edition.cnn.com/2016/11/24/asia/china-xinjiang-passports/ index.html. Accessed 16 August 2017.

Mackerras, Colin. 2001. "Xinjiang at the turn of the century: the causes of separatism." Central Asian Survey 20(3), 289-303.

Mallory, James Patrick, and V.H. Mair. 2000. The Tarim Mummies: Ancient China and the Mystery of the Earliest Peoples from the West. London: Thames \& Hudson.

Moneyhon, Mathew. 2002. "China's great western development project in Xinjiang: economic palliative, or political Trojan Horse?" Denver Journal of International Law and Policy 31(3), 491-523.

Mullaney, Thomas S. 2011. Coming to Terms with the Nation: Ethnic Classification in Modern China. Berkley, CA: University of California Press.

O'Brien, David. 2016. "If there is harmony in the house there will be order in the nation: an exploration of the Han Chinese as political actors in Xinjiang." In Anna Hayes and Michael Clarke (eds.), Inside Xinjiang: Space, Place and Power in China's Muslim Far Northwest. London: Routledge, 32-52. 
Philips, Tom. 2017. "China troops stage show of force in Xinjiang and vow to 'relentlessly beat' separatists," The Guardian, 20 February, https://www.theguardian.com/world/2017/feb/20/ chinese-troops-stage-show-of-force-in-xinjiang-and-vow-to-relentlessly-beat-separatists. Accessed 16 August 2017.

Rudelson, Justin. 1997. Oasis Identities: Uyghur Nationalism along China's Silk Road. New York: Columbia University Press.

Smith, Joanne. 2002. "Making culture matter: symbolic spatial and social boundaries between Uyghurs and Han Chinese." Asian Ethnicity 3(2), 153-174.

Stein, Justin. 2003. "Taking the deliberative turn in China: international law, minority rights and the case of Xinjiang." Journal of Public and International Affairs 14, 1-23.

Stockmann, Daniela. 2010. "Information overload? Collecting, managing, and analyzing Chinese media content." In Allen Carlson, Mary Gallagher, Kenneth Lieberthal and Melanie Manion (eds.), Contemporary Chinese Politics: New Sources, Methods, and Field Strategies. New York: Cambridge University Press, 107-128.

van Dijk, Teun. 1998. Ideology: A Multidisciplinary Approach. London: Sage.

Varutti, Mazia. 2011. "Miniatures of the nation: ethnic minority figurines, mannequins and dioramas in Chinese museums." Museum \& Society 9(1), 1-16.

Xinjiang Uygur Autonomous Region Statistics Bureau. 2012. Xinjiang tongji nianjian (Xinjiang Statistical Yearbook 2012). Beijing: Zhongguo tongji chubanshe.

Ye, Quan. 2015. "Xinjiang ribao yuan zongbianji bei shuangkai, fanbaokong yanlun yu zhongyang buyizhi" (Xinjiang daily editor-in-chief got fired due to inconsistency in his speech on antiterrorism), http://www.chinanews.com/gn/2015/11-02/7600488.shtml. Accessed 2 March 2016.

Yee, Herbert. 2003. "Ethnic consciousness and identity: a research report on Uygur-Han relations in Urumqi." Journal of Contemporary China 12(36), 431-452.

Zenz, Adrian, and James Leibold. 2017. "Xinjaing's rapidly evolving security state." The Jamestown Foundation China Brief 17(4), https://jamestown.org/program/xinjiangs-rapidlyevolving-security-state/. Accessed 16 August 2017. 